\title{
SEDIMENTOLOGY OF BEACHES IN NORTHERN PALM BEACH COUNTY, FLORIDA, USA
}

\author{
SEDIMENTOLOGIA DE PRAIAS NO CONDADO PALM BEACH SETENTRIONAL, \\ FLÓRIDA, EUA
}
SÉDIMENTOLOGIE DES PLAGES DU COMTÉ NORD PALM BEACH, FLORIDE, $\boldsymbol{E U A}$

\author{
NICHOLAS C. BROWN ${ }^{1}$ \\ TIFFANY ROBERTS BRIGGS ${ }^{2}$
}
${ }^{1}$ Department of Geosciences, Florida Atlantic University, Boca Raton, Florida, United States of America.

${ }^{1}$ Department of Geosciences, Florida Atlantic University, Boca Raton, Florida, United States of America. E-mail: briggst@fau.edu.

\begin{abstract}
Beach nourishment is a common strategy for erosion mitigation that also increases coastal resilience to storm impacts, provides habitat, and supports the economy. Regulations often require that placed sediment closely match the native grain size distribution and composition, however characteristics can vary based on the borrow site. Certain sediment properties will also influence beach slope and other critical beach functions. This study evaluates the 3-dimensional sediment properties and beach morphology of nourished and non-nourished barrier island beaches in northern Palm Beach County, Florida, USA. Surveyed beach profiles were compared with predicted slope based on median grain size. The inlet-adjacent beach managed with annual placement of beneficial use of dredged materials consisted of poorly sorted coarse sand and the steepest measured slope. Sediment was progressively finer and better sorted downdrift with decreasing foreshore slopes. Although sediment near the shoreline is typically the coarsest, clasts were finer than the mid-beach location suggesting that the sampling period coincided with beach recovery and onshore sediment transport of finer material. Sediment at the surface differed from sediment at depth, likely due to the frequent introduction of sediment from various borrow areas compared to the dominance of weathered coquina at depth. The non-carbonate, siliciclastic fraction was primary quartz with few other minerals. The estimated beach slope at the location with the coarsest sediment matched the measured slope. A lower beach slope was predicted for the other locations with finer grain sizes at the shoreline that was attributed to slightly steeper slopes associated with beach accretion. Therefore, complicated spatio-temporal morphodynamics of beaches should be considered when using median grain size from only one sampling event.
\end{abstract}

Keywords: Nourished. Non-nourished. Grain size. Beach slope.

\section{RESUMO}

A alimentação de praias é uma estratégia comum para a mitigação da erosão que também aumenta a resiliência costeira aos impactos das tempestades, fornece habitat e apoia a economia. As regulamentações geralmente exigem que o sedimento colocado corresponda muito bem à distribuição e composição do tamanho do grão nativo; no entanto, as características podem variar com base no local de empréstimo. Certas propriedades do sedimento também influenciam o declive e outras funções críticas da praia. Este estudo avalia as propriedades tridimensionais dos sedimentos e a morfologia de ilhas-barreira alimentadas artificialmente e não alimentadas, no Condado Palm Beach Setentrional, Flórida, EUA. Os perfis de praia levantados foram comparados com a inclinação prevista com base no tamanho médio do grão. A praia adjacente à enseada foi analisada com colocação anual de materiais dragados, consistindo em areia grossa mal selecionada, com declive mais íngreme. O sedimento foi progressivamente sendo mais fino e melhor classificado nas encostas decrescentes da costa. Embora o sedimento perto da linha da costa seja tipicamente o mais grosso, os clastos eram mais finos do que no meio da praia, sugerindo que o período de amostragem coincidiu com a recuperação da praia e com o transporte terrestre de sedimentos mais finos. O sedimento na superfície diferia do sedimento em profundidade, provavelmente devido à introdução frequente de sedimento de várias áreas de empréstimo em comparação com a dominância da coquina intemperizada em profundidade. A fração siliciclástica não carbonatada foi definida como sendo quartzo primário com poucos outros minerais. A inclinação estimada da praia no local com o sedimento mais grosso correspondeu à inclinação medida. Uma encosta de praia mais baixa foi prevista para os outros locais com tamanhos de grãos mais finos na linha da costa, o que foi atribuído a encostas ligeiramente mais íngremes associadas ao acúmulo de areais. Portanto, a complicada morfodinâmica espaço-temporal das praias deve ser considerada ao se usar o tamanho médio de grão de apenas um evento de amostragem.

Palavras-chave: Praias alimentadas artificialmente. Praias não alimentadas. Tamanho de grão. Encosta de praia. 


\section{RESUME}

La nourriture des plages est une stratégie courante d'atténuation de l'érosion qui augmente également la résilience côtière aux impacts des tempêtes, fournit un habitat et soutient l'économie. Les réglementations exigent souvent que les sédiments placés correspondent étroitement à la distribution et à la composition granulométriques indigènes, mais les caractéristiques peuvent varier en fonction du site d'emprunt. Certaines propriétés des sédiments influenceront également la pente et d'autres fonctions critiques de la plage. Cette étude évalue les propriétés tridimensionnels des sédiments et la morphologie des plages e de plages d'îles-barrières nourries et non nourries dans le nord du comté de Palm Beach, en Floride, aux États-Unis. Les profils de plage étudiés ont été comparés à la pente prévue en fonction de la taille médiane des grains. La plage adjacente gérée avec le placement annuel d'une utilisation bénéfique des matériaux de dragage était constituée de sable grossier mal trié et de la pente mesurée la plus raide. Les sédiments étaient progressivement plus fins et mieux triés en aval avec une diminution des pentes de l'estran. Bien que les sédiments près du rivage soient généralement les plus grossiers, les clastes étaient plus fins que l'emplacement du milieu de la plage, ce qui suggère que la période d'échantillonnage a coïncidé avec la récupération de la plage et le transport de sédiments sur le rivage de matériaux plus fins. Les sédiments en surface différaient des sédiments en profondeur, probablement en raison de l'introduction fréquente de sédiments provenant de diverses zones d'emprunt par rapport à la dominance de coquines altérées en profondeur. La fraction siliciclastique non carbonatée était du quartz primaire avec peu d'autres minéraux. La pente estimée de la plage à l'emplacement avec les sédiments les plus grossiers correspondait à la pente mesurée. Une pente de plage plus faible a été prévue pour les autres emplacements avec des grains plus fins sur le rivage, ce qui a été attribué à des pentes légèrement plus raides associées à l'accrétion de la plage. Par conséquent, la morphodynamique spatio-temporelle compliquée des plages doit être prise en compte lors de l'utilisation de la taille de grain médiane d'un seul événement d'échantillonnage.

Mots-clés: Nourriture de plages. Non nourriture de plages. Taille d'un grain. Pente de la plage.

\section{INTRODUÇÃO}

Beaches provide recreation, habitat, reduction of storm impacts, and serve as an economic driver. As these functions become threatened by erosion, a common solution is beach nourishment, which places sand on a beach to mitigate erosion and advance the shoreline seaward (DAVIS et al., 2000; DEAN, 2003). Understanding the implications of certain physical properties of sediment placed on beaches are important to ensure they continue to provide benefits and functionality. This study evaluates the 3-dimensional sediment characteristics and beach morphology along $12 \mathrm{~km}$ of beach in Northern Palm Beach County, Florida (USA) that includes segments with annual placement of beneficial use of dredged material (BUDM), periodic beach nourishment projects, and a non-nourished beach.

The borrow source sediment used for beach nourishment should be compatible to the native sediment (HOUSTON, 2017). However, sediment properties can vary between common borrow sources such as inlets, offshore, or upland mines (DEAN, 2003; CISNEROS et al., 2017). More than $95 \%$ of all sand volume placed for shore protection nourishment projects are through offshore dredging of compatible sediment (DEAN, 2003). Offshore sources generally are reworked shelf sediments and sand ridges from previous sea levels (FINKL et al., 2005), and dredging targets the layers most suitable for beach placement (FINKL; KHALIL, 2005). Inlets are another source of beach sediment as many must be periodically dredged for navigational maintenance. Rather than offshore disposal, more recently in the US dredged sediment are placed on adjacent beaches as "beneficial use of dredged material" (BUDM). Sediments from inlets can consist of more poorly sorted sediment with larger grain sizes due to the accumulation of the larger sediments within the main channel (i.e., thalweg) resisting advection (WANG; BEAK, 2012). Despite the different characteristics of inlet thalweg, placing sediment on the downdrift beaches keeps that sediment from being lost from the littoral system and mitigate erosional effects from the interruption of longshore sediment transport. Upland mines are another source of nourishment sediment but can have a smaller mean grain size and better sorting than typical beach sediment due to the dominance of terrestrial or paleoprocesses compared to the high-energy processes at the coast (OAI; CPE, 2012).

In the US, geotechnical studies of sediment suitability for nourishment are required prior to placing sand on a beach (USACE, 2019a; 2019b). However over time, sediment properties on the beach might vary from the initial placed sediment due to selective transport 
(BLACKLEY; HEATHERSHAW, 1982; KOMAR; WANG, 1984; DE MEIJER et al., 2002; HORN; WALTON, 2007; LACEBY et al., 2017), storm-driven transport (ROBERTS et al., 2013), or with recurring projects using different sediment sources (LACEBY et al., 2017). Certain textural and compositional sediment properties influence beach slope (KOMAR; MCDOUGAL, 1994; KRAUS; GALGANO, 2001, KARUNARATHNA et al., 2012; LEADON, 2015; MCFALL, 2019), permeability (MCLEAN; KIRK, 1964; REIS; GAMMA 2009; KARUNARATHNA et al., 2012), and substrate temperature (MILTON et al., 1997). Although generally accepted that grain size influences the angle of repose, and therefore beach slope (KOMAR; MCDOUGAL, 1994), Reis and Gamma (2009) found that grain size is not entirely proportional to the beach face gradient. In contrast, McFall (2019) analyzed global beach sands and derived predictive equations for beach slope based on the sediment grain size (for median grain size of $<1 \mathrm{~mm}$ ). On open coastlines facing the dominant wave direction and not protected by coastal structures, classification was based on offshore significant wave height exceeding 12 hours per year $\left(\mathrm{H}_{\mathrm{s}, 12 \mathrm{~h} / \mathrm{y}}\right)$. Exposed beaches were identified as $\mathrm{H}_{\mathrm{s}, 12 \mathrm{~h} / \mathrm{y}}>3 \mathrm{~m}$, moderately exposed as $\mathrm{H}_{\mathrm{s}, 12 \mathrm{~h} / \mathrm{y}}$ between 1 and $3 \mathrm{~m}$, and protected as $\mathrm{H}_{\mathrm{s}, 12 \mathrm{~h} / \mathrm{y}}<1 \mathrm{~m}$. Predictions for each beach exposure were based on the inverse beach face slope $(\mathrm{X})$ :

$$
X=A d^{n}
$$

where $\mathrm{d}$ is median grain size in millimeters, $\mathrm{A}$ is a derived coefficient, and $\mathrm{n}$ is a derived exponent. The following equations were derived based on 181 samples to estimate beachface slope of each beach exposure type:

$$
\begin{aligned}
& \text { Protected: } X=3.1 d^{-1.1} \\
& \text { Moderately protected: } X=2.1 d^{-1.8} \\
& \text { Exposed: } X=3.9 d^{-1.85}
\end{aligned}
$$

The extent of wave runup can also be influenced by the slope and sediment size, with implications for the ecosystem services of beaches (BASCOM, 1951; WIEGAL, 1964; DINGLER; REISS, 2002). Increased wave runup from storms and increasing sea level will adversely impact sea turtle nests and increase mortality of eggs laid in low-lying locations (FUENTES et al., 2010; PIKE et al., 2015). Sediment properties effect the success of sea turtle nests (MORTIMER, 1981; MORTIMER, 1990; MORTIMER, 1995), influencing temperature (ANDREW, 1995; MILTON et al., 1997; TURKOZAN et al., 2011), moisture content (ANDREW, 1995; TURKOZAN et al., 2011), reflectivity (ANDREW, 1995), oxygen exchange (ANDREW, 1995; CHEN et al., 2010), and the slope conducive for nesting (WOOD; BJORNDAL, 2000; RIZKALLA; SAVAGE, 2011; TURKOZAN et al., 2011).

\section{STUDY AREA}

In Florida, $87 \%$ of the coast is considered "critically eroded" (FDEP, 2016) with more than 750 nourishment projects placing over 248 million cubic meters of sediment beaches since 1934 (National Beach Nourishment Database, 2020). Florida state regulations require that shore protection projects place no more than $5 \%$ of fine material on beaches and that sediment is compatible with the native beach sediment in composite mean grain size (OUSLEY et al., 2014). Sediments on Florida's large carbonate platform range from Jurassic to Holocene in age. Clastic material has been accumulating in quantities large enough to be observed with the 
carbonate since the Miocene from erosion of the Appalachian Mountains, transported via alluvial and coastal processes (WALKER et al., 1983; SCOTT, 1997). Many heavier minerals (e.g., less complex silicate polymers) are less resistant to erosion (GOLDICH, 1938) and result in fewer "heavies" found far from the source. The sediment found along the eastern coast of Florida is comprised of widely varying percentages from the alluvially transported provenance clasts (allochthonous), reworked shelf sediment (mixture of allochthonous and autochthonous), and biogenic clasts (autochthonous) (GOLDICH, 1938; SCOTT, 1997). Along large portions of Florida's east coast, weathering of the coquinoid Anastasia Formation outcropping at the shoreline is also an important contributor of carbonate clasts.

Figure 1 - Study sites including nourished and non-nourished beaches in northeastern Palm Beach County, Florida, USA.

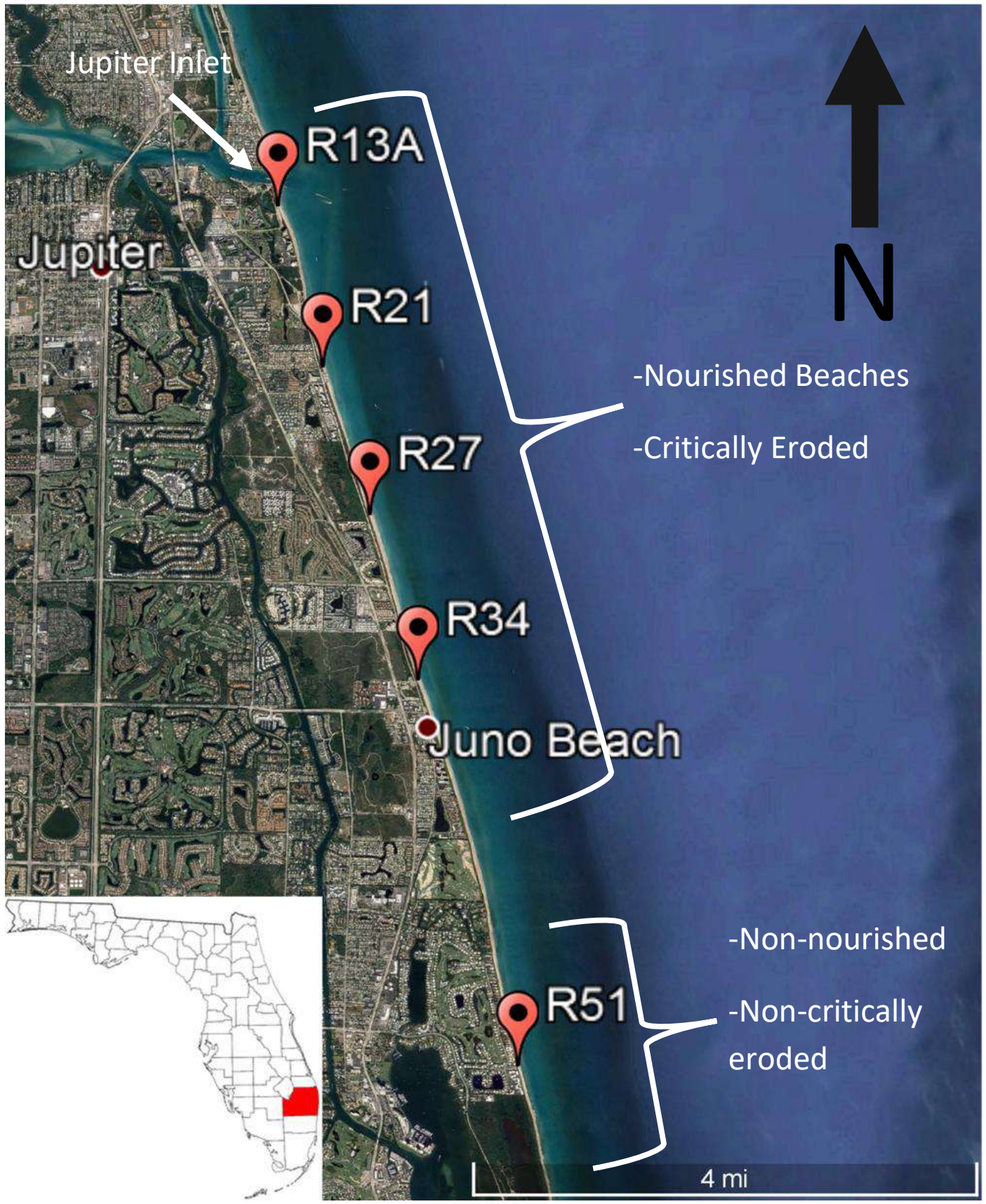


This study focuses on the northern $12 \mathrm{~km}$ of Palm Beach County, FL, USA (Figure 1). Palm Beach County has both nourished and non-nourished beaches that are classified as intermediate with a longshore bar and trough morphology (BENEDET et al., 2006). The coquioid Anastasia Formation outcrops up to 2 m (NAVD88) on the beach and provides patches of sub-planar hardbottom in the nearshore. The dominant direction of longshore sediment transport is south, but seasonal reversals occur moving sediment north in the summer. The stretch of beach analyzed in this study are considered critically eroded (FDEP, 2016). The northern-most sites (R13A and R21) in the city of Jupiter is nourished annually with BUDM through a management plan adopted in 1997 to bypass $57,341 \mathrm{~m}^{3}$ of sediment each year. Federally managed projects were constructed in 1995, 2002, and 2015 with a total of 1,047,440 $\mathrm{m}^{3}$ of sediment placed (FDEP, 2018), and another project completed in early 2020. Numerous additional local projects have been constructed using sediment from upland sources $(251,790$ $\mathrm{m}^{3}$ ), dredged material from the Atlantic Intracoastal Water Way $\left(78,036 \mathrm{~m}^{3}\right)$, and sediment from an inlet sand trap $\left(82,696 \mathrm{~m}^{3}\right)$ (FDEP, 2018; National Beach Nourishment Database, 2020). Juno Beach (R 27 and R34) is located south of Jupiter and has been nourished in 2001 and 2010 using offshore borrow sites placing a total of $1,847,311 \mathrm{~m}^{3}$ of sediment (FDEP, 2018). The study also includes a non-nourished site to the south (R51).

\section{METHODS}

Five locations were analyzed in the spring of 2019 along a $12 \mathrm{~km}$ study area, with transects spaced approximately $2 \mathrm{~km}$ apart from the Jupiter Inlet to just north of a state park (Figure 1). From north to south, the locations include an inlet-adjacent beach receiving annual BUDM (R13A), locations with periodic construction of shore protection projects (R21, R27, and R34) and a non-nourished control beach (R51).

A total of 30 sediment samples were collected at the surface ("S") and at a depth of 75 cm ("75") at the dune toe (high, "H"), mid-beach (mid, "M"), and Mean High Water Line (low, "L") along the five transects and analyzed for composition and granulometric properties. Munsell color was determined for each sample and then sieved using a W.S. Tyler Ro-Tap Mechanical Sieve Shaker and Standard 8" full-height brass Test Sieves at half phi size intervals between -4 and $2 \phi$, and at quarter phi intervals between 2 and $4 \phi$. Percent carbonate was determined by hydrochloric acid dissolution. The remaining non-carbonate, siliciclastic fraction was then re-sieved. Statistical analysis was completed using the moment method to determine mean, median, standard deviation (sorting), skewness, and kurtosis for both the bulk sample and non-carbonate fraction (BOGGS, 2014). Photos of the sediment samples and optical mineral analysis were conducted using a Leica M125 C microscope on bulk and non-carbonate fractions for all sediment samples. Qualitative observations were made for mineralogic composition, roundness, and a general identification of the carbonate fragments (e.g., bivalve, gastropod, coral).

Survey transects at the five locations were established using a Real-Time Kinematic Global Positioning System (RTK GPS). Beach profiles were collected using traditional level and transit procedures with a Spectra Precision Total Station from the seaward-side of the foredune to approximately 2-3 m water depth. Data from R21 to R51 were collected on 4/10/19. R13A was sampled on 5/8/19 because of an active BUDM placement project on the original sampling date. Foreshore slope at each transect was measured between approximately $1.0 \mathrm{~m}$ to $-0.5 \mathrm{~m}$ elevation (NAVD88). Measured slopes were then compared with the McFall (2019) predictive equations for protected, moderately protected, and exposed beaches using the median grain size from the mean high water sediment samples. 


\section{RESULTS}

\section{Bulk Sediment Properties}

Surface sample sedimentology varied alongshore and cross-shore at each location (Figure 2 ). The most poorly sorted and coarse sediment was located at R13A. Downdrift, sediment generally became progressively finer and better sorted (except at the dune toe at R34). Sediment was coarser at the mid-beach than the dune toe, as expected. However, sediment at the MHW was the finest (except at R13A). At depth, increased sorting and fining downdrift was also measured (Figure 3). At depth, the cross-shore distribution of sediment followed the typical pattern of increased fining from the MHW to the mid-beach to the dune. Sediment at the nonnourished beach was similar to the nourished beaches (except at R13A).

Figure 2 - Example visual of the bulk fraction sediment at the surface from the mid-beach locations. (10x zoom).
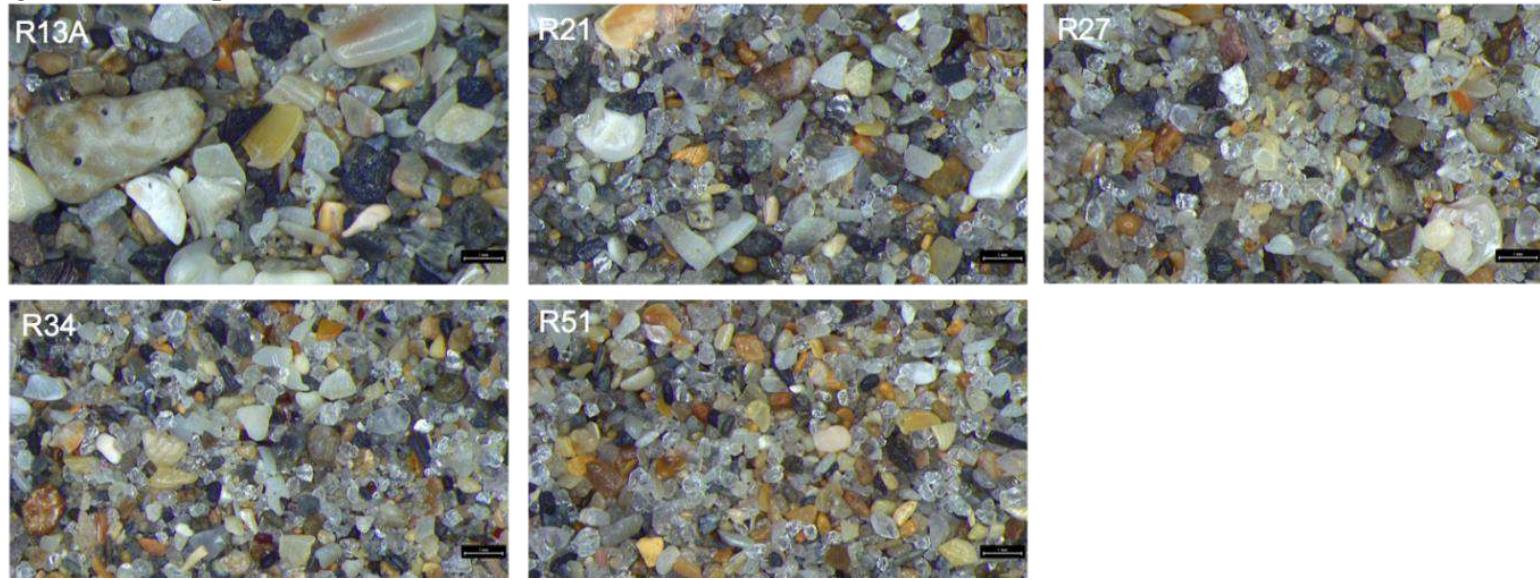

Source: the authors.

Figure 3 - Surface sample mean and sorting at the high, mid, and low beach from north to south (R13A to R51).

Bulk Sediment at Surface

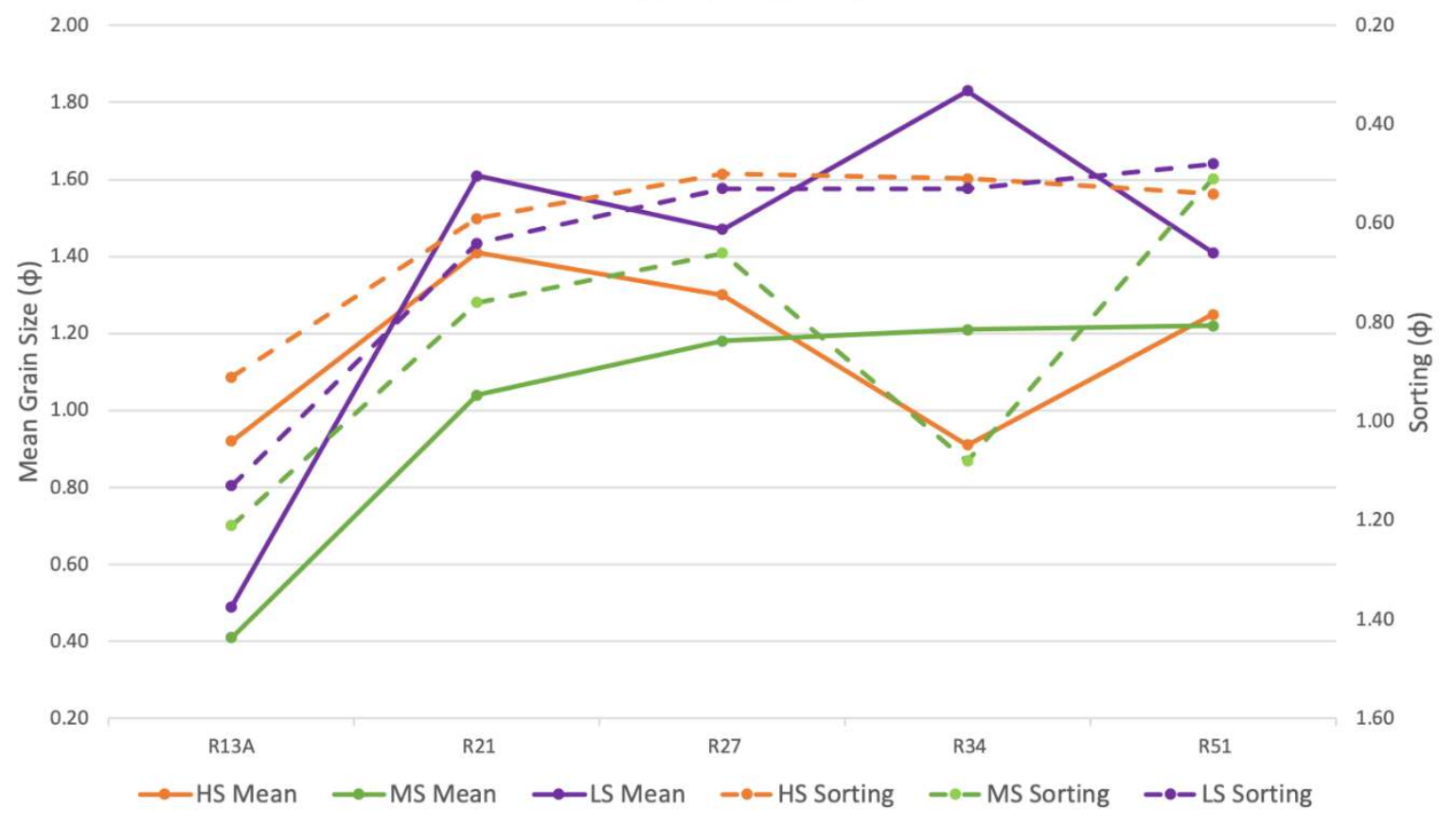

Source: the authors. 
Sediment at the Mean High Water (MHW) and mid-beach at the BUDM-influenced R13A were poorly sorted coarse sand (0.00-1.00 $\pm 1.00-2.00 \varphi)$ (Table 1). At the dune toe, sediment was moderately sorted $(0.71-1.00 \varphi)$ coarse sand at the surface and moderately sorted medium sand at depth $(0.71-1.00 \varphi)$. Surface sediment carbonate content increased from the dune to the MHW from $70 \%, 76 \%$, and $82 \%$ at the dune, mid-beach, and MHW, respectively. At the MHW and mid-beach, carbonate content increased with depth to $84 \%$ and $78 \%$, respectively. However, at the dune, the carbonate content decreased to 64\%. A smaller grain size and lower carbonate content is expected for the aeolian-dominated dune toe, but also likely different due to the annual placement of shelly dredge material placed across the beach seaward of that location. All carbonate grains were sub-rounded, and consisted of bivalves, coral fragments, and semi-rare gastropods (Figure 4). Numerous large bivalve fragments along with other unidentifiable large fragments regularly exceeded $2 \mathrm{~mm}$ on the longest axis. The color of the sediments that were in this sample were light gray (5Y 7/1) and gray (5Y 6/1).

Figure 4 - Mean and sorting of samples taken at $75 \mathrm{~cm}$ depth at the high, mid, and low beach from north to south (R13A to R51).

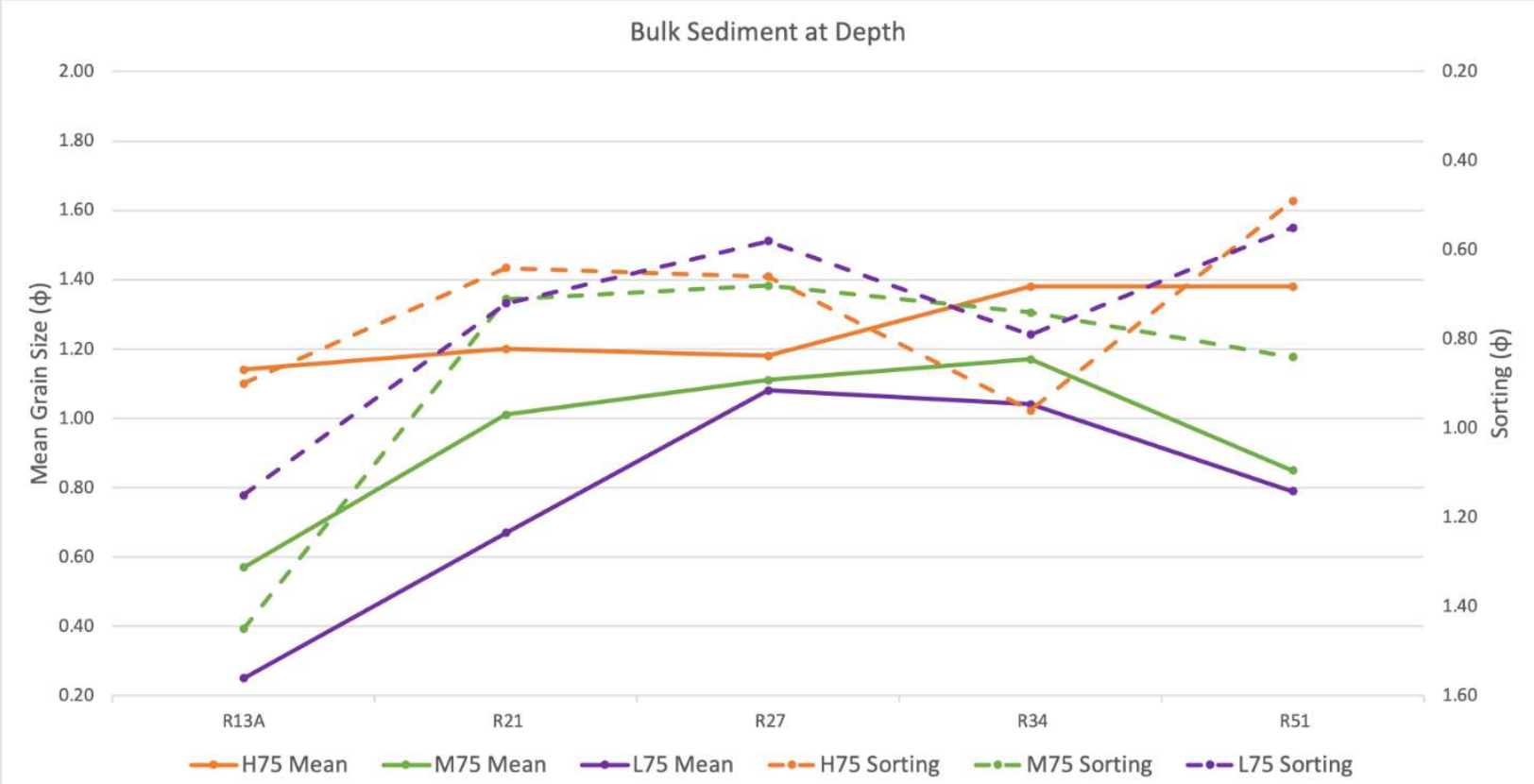

Source: the authors.

Sediment at most cross-shore locations at the nourished R21 transect were moderately well-sorted medium sand (1.00-2.00 $\varphi \pm 0.50-0.71 \varphi)$ with the exception of the mid beach surface sediment which was moderately sorted medium sand (1.00-2.00 $\varphi \pm 0.71-1.00 \varphi)$ (Table 1) and the MHW sample taken at depth which was moderately sorted coarse sand $(0.00-1.00 \varphi \pm 0.71$ $1.00 \varphi)$. Surface carbonate increased from the dune toe $(47 \%)$ seaward to the mid-beach $(59 \%)$ and increased with depth across the transect from $48 \%$, to $55 \%$, to $68 \%$ for the dune toe, midbeach, and MHW, respectively. The exception to the overall increase was the MHW surface sample where the carbonate percentage decreased to $40 \%$. Few carbonate grains exceeding 2 $\mathrm{mm}$ in length on the longest axis were measured at R21 with most grains being under this size (Figure 4). Carbonate materials were rounded to subrounded with some well-rounded grains. The color of the sediments that were in this sample were light gray (5Y 7/1).

Sediment at the nourished R27 transect were moderately well-sorted medium sand (1.00$2.00 \varphi \pm 0.50-0.71 \varphi$ ) (Table 1). Sediment overall was finer on the surface than at depth across the transect. The carbonate at the surface was $46 \%, 47 \%$, and $43 \%$ at the dune toe, mid-beach, 
and MHW, respectively. At depth, the sediment was higher in carbonate content than the surface and was highest in carbonate content near the dune with $58 \%, 54 \%$, and $53 \%$ at the dune toe, mid-beach, and MHW. Carbonate grains rarely exceeded $2 \mathrm{~mm}$ on the longest axis and materials observed were rounded to subrounded with some well-rounded grains (Figure 4). The color of the sediments that were in this sample were light gray (5Y 7/1) and gray (5Y 6/1).

Sediment mean grain size at the nourished R34 transect were medium sand $(1.00-2.00 \varphi)$ with the exception of the dune toe surface sample that was coarse sand $(0.00-1.00 \varphi)$ (Table 1 , Figure 2). The sorting across R34 varied with the surface samples with moderately well sorted $(0.50-0.71 \varphi)$ at the dune toe and MHW, moderately sorted $(0.71-1.00 \varphi)$ at depth, and poorly sorted $(1.00-2.00 \varphi)$ at the mid-beach surface. Carbonate content for surface sediment was similar to R21 and R27 with 54\%, 56\%, and 43\% for the dune toe, mid-beach, and MHW, respectively. At depth, the carbonate content increased seaward from $57 \%$, to $58 \%$, and $61 \%$ for dune toe, mid-beach, and MHW. The carbonate material rarely exceeded $2 \mathrm{~mm}$ in grain size on the longest axis and was found to be rounded to subrounded with some well-rounded grains (Figure 4). The color of the sediments that were in this sample were light gray (5Y 7/1) and gray $(5 \mathrm{Y} 6 / 1)$.

Table 1 - Bulk Sediment Data.

\begin{tabular}{|l|l|l|l|l|}
\hline Sample \# & \%Carbonate & Mean $(\boldsymbol{\varphi})$ & Mean $(\mathbf{m m})$ & Sorting $(\boldsymbol{\varphi})$ \\
\hline R13A LS & 82 & 0.49 & 0.71 & 1.13 \\
\hline R13A L75 & 84 & 0.25 & 0.84 & 1.15 \\
\hline R13A MS & 76 & 0.41 & 0.75 & 1.21 \\
\hline R13A M75 & 78 & 0.57 & 0.67 & 1.45 \\
\hline R13A HS & 70 & 0.92 & 0.53 & 0.91 \\
\hline R13A H75 & 64 & 1.14 & 0.45 & 0.90 \\
\hline R21 LS & 40 & 1.61 & 0.33 & 0.64 \\
\hline R21 L75 & 68 & 0.67 & 0.63 & 0.72 \\
\hline R21 MS & 59 & 1.04 & 0.49 & 0.76 \\
\hline R21 M75 & 55 & 1.01 & 0.50 & 0.71 \\
\hline R21 HS & 47 & 1.41 & 0.38 & 0.59 \\
\hline R21 H75 & 48 & 1.20 & 0.44 & 0.64 \\
\hline R27 LS & 43 & 1.47 & 0.36 & 0.53 \\
\hline R27 L75 & 53 & 1.08 & 0.47 & 0.58 \\
\hline R27 MS & 47 & 1.18 & 0.44 & 0.66 \\
\hline R27 M75 & 54 & 1.11 & 0.46 & 0.68 \\
\hline R27 HS & 46 & 1.30 & 0.41 & 0.50 \\
\hline R27 H75 & 58 & 1.18 & 0.44 & 0.66 \\
\hline R34 LS & 43 & 1.83 & 0.28 & 0.53 \\
\hline R34 L75 & 61 & 1.04 & 0.49 & 0.79 \\
\hline R34 MS & 56 & 1.21 & 0.43 & 1.08 \\
\hline R34 M75 & 58 & 1.17 & 0.44 & 0.74 \\
\hline R34 HS & 54 & 0.91 & 0.53 & 0.51 \\
\hline R34 H75 & 57 & 1.38 & 0.38 & 0.96 \\
\hline
\end{tabular}




\begin{tabular}{|l|l|l|l|l|} 
R51 LS & 48 & 1.41 & 0.38 & 0.48 \\
\hline R51 L75 & 65 & 0.79 & 0.58 & 0.55 \\
\hline R51 MS & 52 & 1.22 & 0.43 & 0.51 \\
\hline R51 M75 & 66 & 0.85 & 0.55 & 0.84 \\
\hline R51 HS & 50 & 1.25 & 0.42 & 0.54 \\
\hline R51 H75 & 48 & 1.38 & 0.38 & 0.49 \\
\hline
\end{tabular}

Source: the authors.

Surface and at depth sediments at the non-nourished R51 at the dune toe were medium

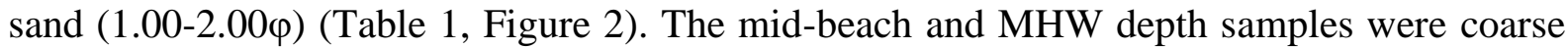
sand $(0.00-1.00 \varphi)$. The dune toe and mid-beach, and MHW depth sample were moderately well sorted $(0.50-0.71 \varphi)$, the dune toe at depth and MHW surface were well sorted $(0.35-0.50 \varphi)$, and the mid-beach depth sample was moderately sorted $(0.71-1.00 \varphi)$. A similar trend of carbonate content occurred across the beach with 50\%, 53\%, 48\% at the dune toe, mid-beach, and MHW. Carbonate at depth was $48 \%, 66 \%$, and $65 \%$ for the dune toe, mid-beach, and MHW, respectively, which was lower than other locations at the MHW. The carbonate material here rarely exceeded $2 \mathrm{~mm}$ in size and was rounded to subrounded with some well-rounded grains (Figure 4). The color of the sediments that were in this sample were light brownish gray $(2.5$ Y $6 / 2)$.

\section{Non-carbonate Siliciclastic Sediment Properties}

The texture of the non-carbonate siliciclastic fraction was more similar cross-shore and alongshore at the surface than at depth (Figure 5). The dune toe and mid-beach sediments were coarser than the MHW, similar to the pattern observed in the bulk fraction. There was also an overall increase in sorting downdrift. Siliciclastic sediment at depth showed more variability that at the surface but followed the typical trend of coarser grains at the MHW as compared to the mid-beach or dune toe (Figure 6).

Figure 5 - Non-carbonate siliciclastic mean and sorting of surface samples at the high, mid, and low beach from north to south (R13A to R51).

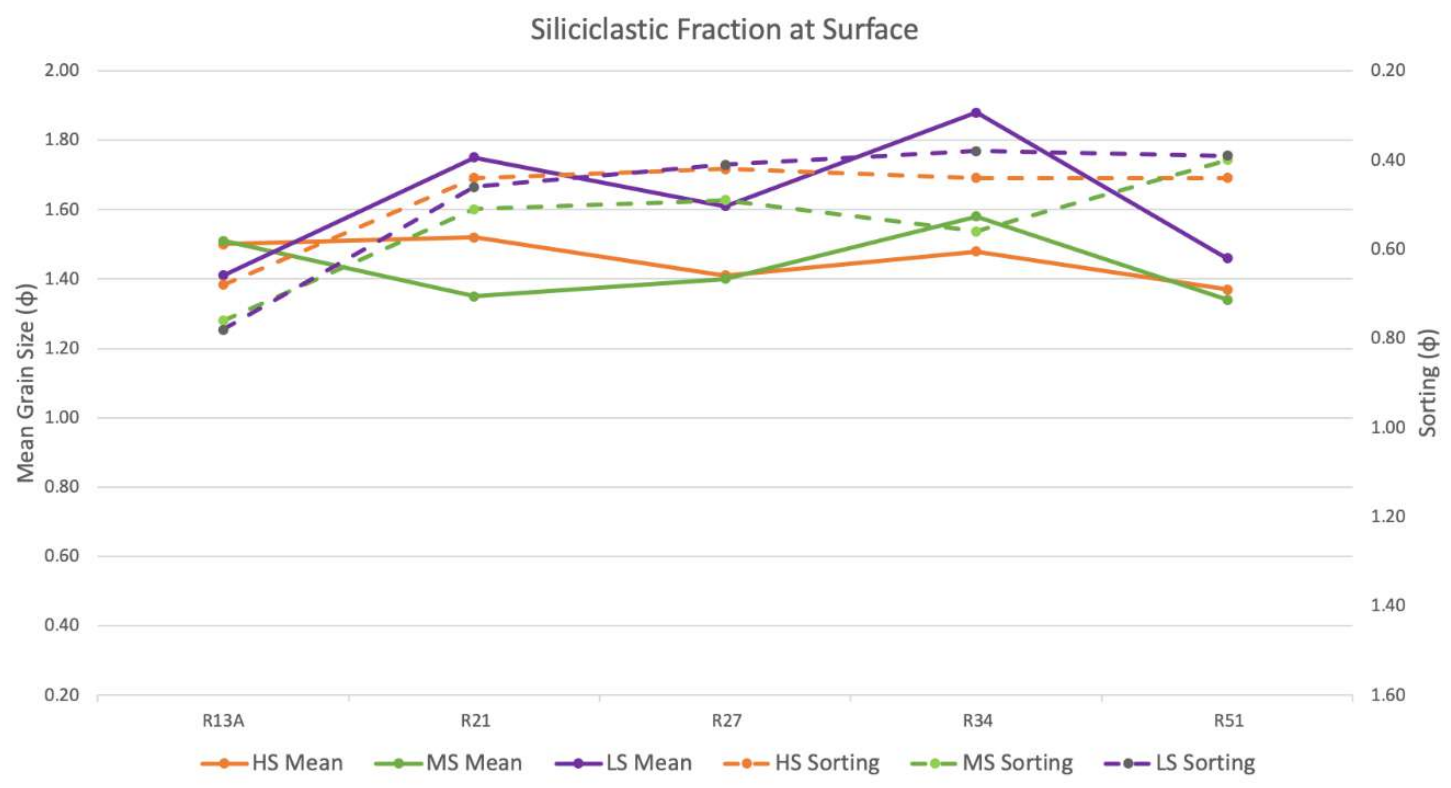

Source: the authors. 
Figure 6 - Non-carbonate siliciclastic mean and sorting of samples at $75 \mathrm{~cm}$ depth at the high, mid, and low beach from north to south (R13A to R51).

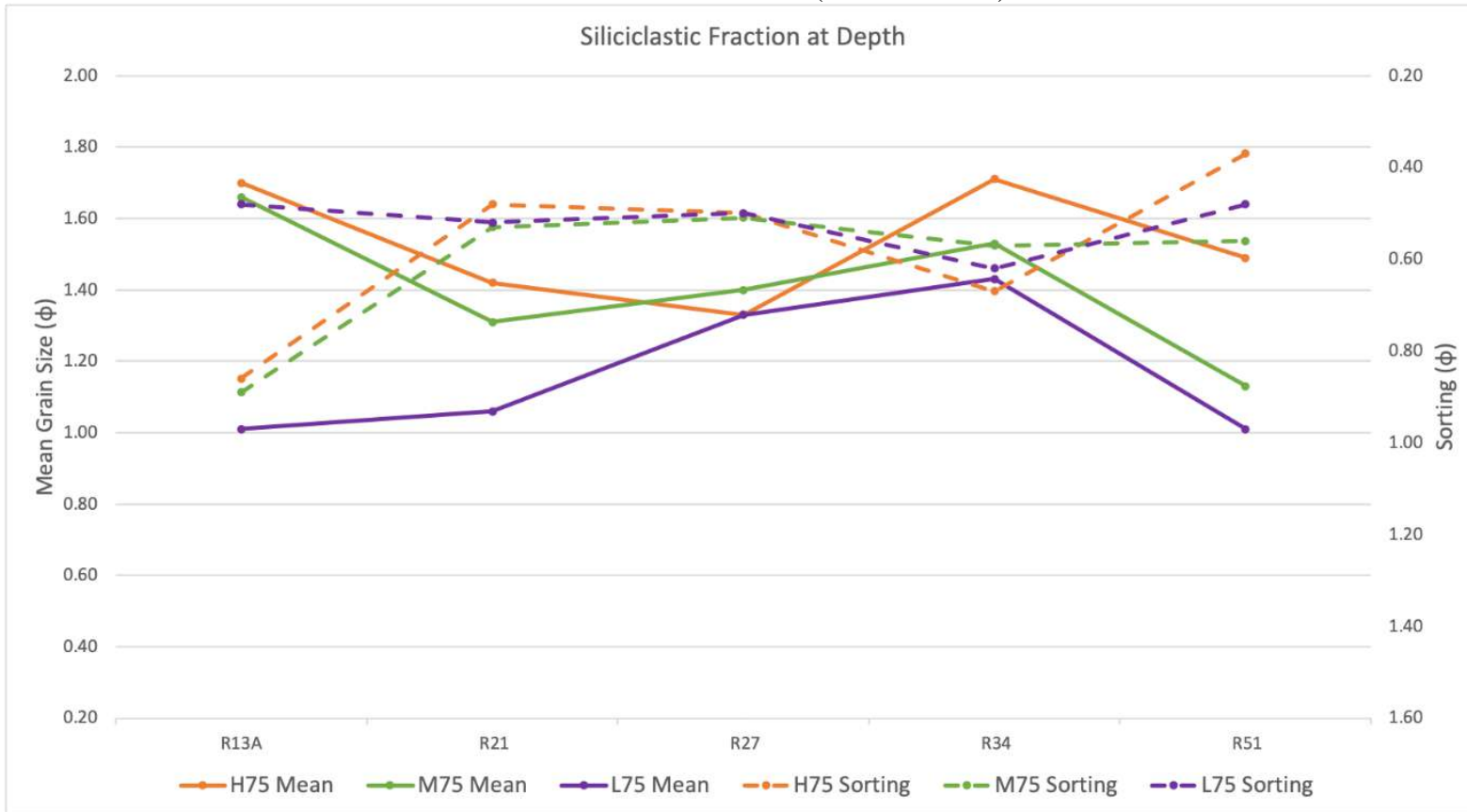

Source: the authors.

At R13A, sediment was generally moderately sorted medium sand (1.00-2.00 $\varphi \pm 0.71$ $1.00 \varphi)$, with moderately well sorted medium sand $(1.00-2.00 \varphi \pm 0.50-0.71 \varphi)$ at the dune toe surface and well sorted medium sand $(1.00-2.00 \varphi \pm 0.35-0.50 \varphi)$ at depth at the MHW. Siliciclastic sediment from R21 were all on the border between well sorted and moderately well sorted (between $\pm 0.44-0.53 \varphi)$ medium sand $(1.00-2.00 \varphi)$. Sediment at the surface were finer than those at depth. At R27, sediment was well sorted $( \pm 0.35-0.50 \varphi)$ medium sand $(1.00-2.00 \varphi)$ with moderately well sorted medium sand $(1.00-2.00 \varphi \pm 0.50-0.71 \varphi)$ at depth at the mid-beach. Siliciclastic sediment at R34 were moderately well sorted medium sand (1.00-2.00 $\varphi \pm 0.50$ $0.71 \varphi)$ with well sorted $( \pm 0.35-0.50 \varphi)$ at the dune tow and MHW surface. At R51, sediment was well sorted medium sand $(1.00-2.00 \varphi \pm 0.35-0.50 \varphi)$ with moderately well sorting $( \pm 0.50$ $0.71 \varphi$ ) at depth at the mid-beach (Table 2).

Table 2 - Non-carbonate (NC) fraction sediment data.

\begin{tabular}{|l|l|l|l|}
\hline Sample \# & $\begin{array}{l}\text { Mean } \\
(\boldsymbol{\varphi})\end{array}$ & Mean $(\mathbf{m m})$ & Sorting $(\boldsymbol{\varphi})$ \\
\hline R13A LS NC & 1.41 & 0.38 & 0.78 \\
\hline R13A L75 NC & 1.01 & 0.50 & 0.48 \\
\hline R13A MS NC & 1.51 & 0.35 & 0.76 \\
\hline R13A M75 NC & 1.66 & 0.32 & 0.89 \\
\hline R13A HS NC & 1.50 & 0.35 & 0.68 \\
\hline R13A H75 NC & 1.70 & 0.31 & 0.86 \\
\hline R21 LS NC & 1.75 & 0.30 & 0.46 \\
\hline R21 L75 NC & 1.06 & 0.48 & 0.52 \\
\hline R21 MS NC & 1.35 & 0.39 & 0.51 \\
\hline R21 M75 NC & 1.31 & 0.40 & 0.53 \\
\hline R21 HS NC & 1.52 & 0.35 & 0.44 \\
\hline
\end{tabular}




\begin{tabular}{|l|l|l|l|} 
R21 H75 NC & 1.42 & 0.37 & 0.48 \\
\hline R27 LS NC & 1.61 & 0.33 & 0.41 \\
\hline R27 L75 NC & 1.33 & 0.40 & 0.50 \\
\hline R27 MS NC & 1.40 & 0.38 & 0.49 \\
\hline R27 M75 NC & 1.40 & 0.38 & 0.51 \\
\hline R27 HS NC & 1.41 & 0.38 & 0.42 \\
\hline R27 H75 NC & 1.33 & 0.40 & 0.50 \\
\hline R34 LS NC & 1.88 & 0.27 & 0.38 \\
\hline R34 L75 NC & 1.43 & 0.37 & 0.62 \\
\hline R34 MS NC & 1.58 & 0.33 & 0.56 \\
\hline R34 M75 NC & 1.53 & 0.35 & 0.57 \\
\hline R34 HS NC & 1.48 & 0.36 & 0.44 \\
\hline R34 H75 NC & 1.71 & 0.31 & 0.67 \\
\hline R51 LS NC & 1.46 & 0.36 & 0.39 \\
\hline R51 L75 NC & 1.01 & 0.50 & 0.48 \\
\hline R51 MS NC & 1.34 & 0.40 & 0.40 \\
\hline R51 M75 NC & 1.13 & 0.46 & 0.56 \\
\hline R51 HS NC & 1.37 & 0.39 & 0.44 \\
\hline R51 H75 NC & 1.49 & 0.36 & 0.37 \\
\hline & Source: the authors. & \\
\hline & &
\end{tabular}

The non-carbonate siliciclastic sediment at all locations were relatively similar in appearance (Figure 7). The Munsell color of all sediments was white (2.5Y 9.5/1). Samples at R13A, R21, and R27 contained at least 95\% clear or white silica and R34 and R51 contained at least $90 \%$ clear or white quartz. Sediment in the samples varied between rounded and subrounded in texture. The other grains that were not the white or clear silica consisted of black and infrequent other colored silica fragments (green, blue, purple, pink, reddish-brown) that were often smaller in size than the quartz grains.

Figure 7 - Example visual of non-carbonate siliciclastic fraction sediment samples at the surface of the mid-

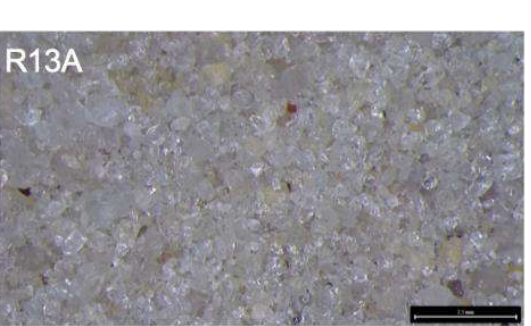
beach (10x zoom).
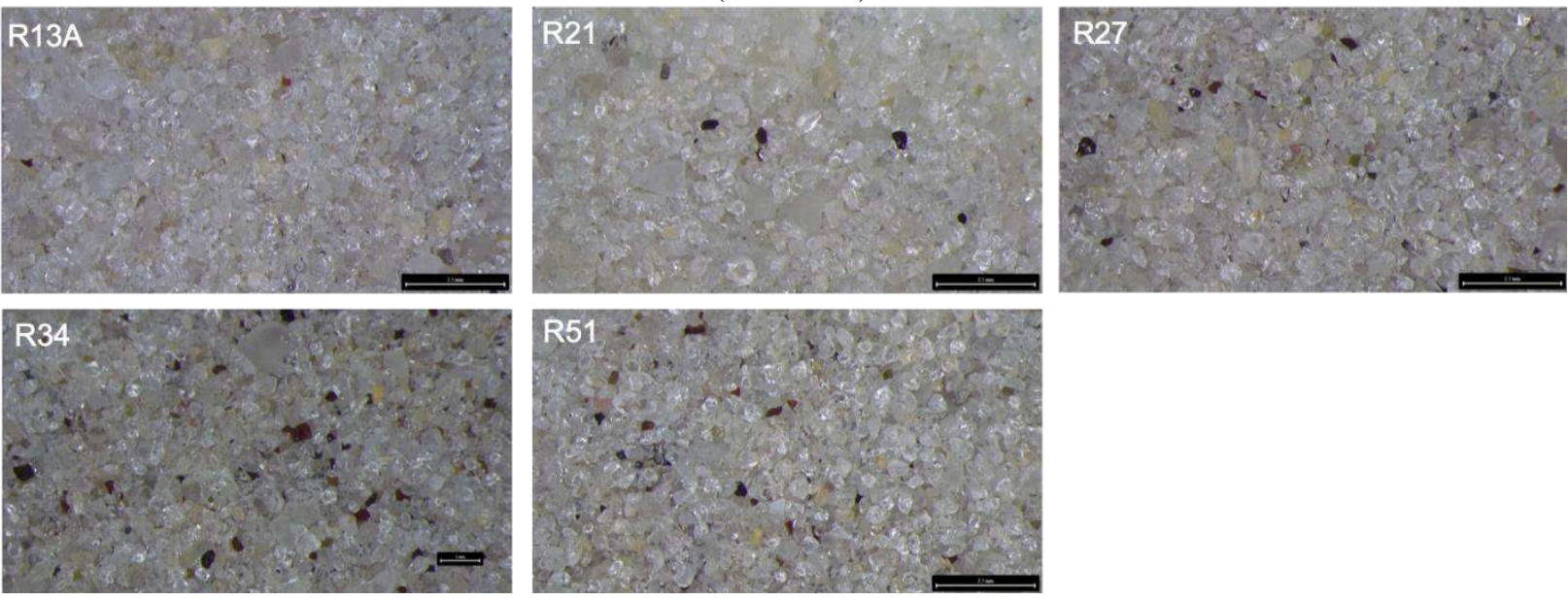

Source: the authors. 


\section{Beach Profiles and Foreshore Slope}

The two northern-most locations, R13A and R27 had a more overall convex shape and higher foreshore slopes as compared to the other sites (Figure 8). The beach at R13A was nourished with BUDM in April 2019, just prior to data collection, constructing a berm that was comparatively $20 \mathrm{~m}$ wider and the highest backbeach elevation. This location also had the steepest foreshore slope of 1:7 (vertical:horizontal). The foreshore at R21 was also comparatively steep, with a slope of 1:8. Between R27 and R51, beaches had an overall concave morphology with a seaward dipping planar foreshore. The dune at R27 extended $\sim 8 \mathrm{~m}$ further seaward than other locations and R34 had a large scarp at roughly $10 \mathrm{~m}$. The foreshore slope at R27 was $1: 11$ and 1:12 at R34. Further south, the slope continued to decrease at R51 with a 1:14 slope.

Figure 8 - Beach profiles measured in the spring of 2019 at the five study sites.

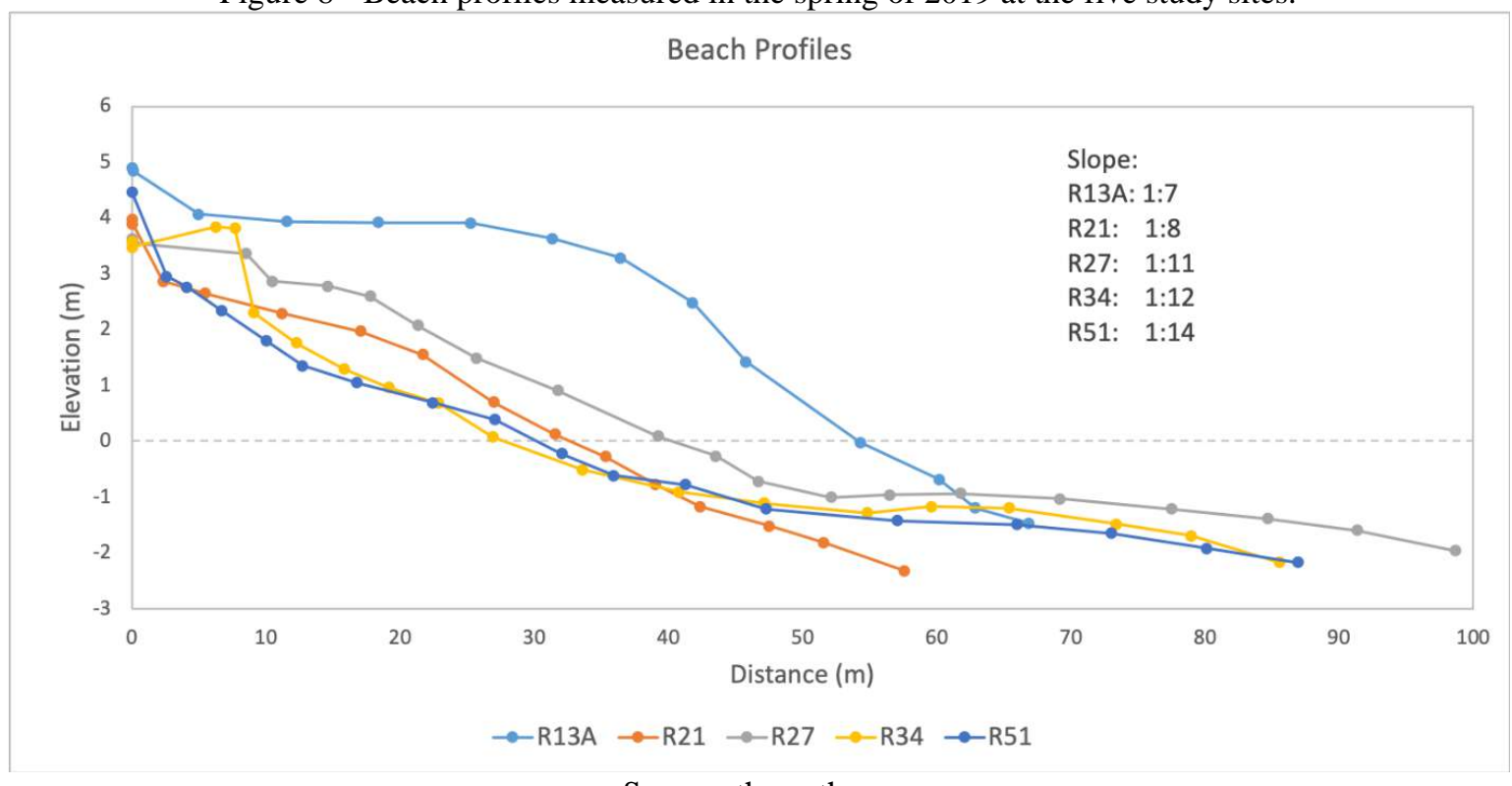

Source: the authors.

The measured foreshore slopes were compared to the predicted slope under all three scenarios of exposure (Table 3). For all locations, the predictive equation for a protected beach most closely matched the measured slopes. At R13A, both the predicted and measured beach slope were 1:7. Although the measured slopes progressively became less steep to the south between R21 and R24, the predicted slope was the same (1:15). At the southern-most site, R51, the predicted slope of 1:13 nearly matched the measured slope of 1:14.

Table 3 - Measured beach slope compared to predicted slope (best fit shown in bold)

\begin{tabular}{|l|l|l|l|l|l|}
\hline Location & R13A & R21 & R27 & R34 & R51 \\
\hline Median grain size (mm) & 0.48 & 0.24 & 0.25 & 0.22 & 0.27 \\
Measured slope & $1: 7$ & $1: 8$ & $1: 11$ & $1: 12$ & $1: 14$ \\
Protected (Eq. 2) & $\mathbf{1 : 7}$ & $\mathbf{1 : 1 5}$ & $\mathbf{1 : 1 5}$ & $\mathbf{1 : 1 5}$ & $\mathbf{1 : 1 3}$ \\
Mod. protected (Eq. 3) & $1: 8$ & $1: 30$ & $1: 30$ & $1: 30$ & $1: 25$ \\
Exposed (Eq. 4) & $1: 15$ & $1: 60$ & $1: 50$ & $1: 65$ & $1: 50$ \\
\hline
\end{tabular}

Source: the authors. 


\section{DISCUSSION}

Annual placement of coarse sediment from the adjacent inlet channel maintenance as BUDM resulted in the coarsest sediment at R13A. Whereas the beach and MHW locations had higher carbonate content and larger grain sizes due to the properties of the inlet thalweg, sediment at the dune toe was more similar to downdrift beaches because the BUDM were placed seaward of the dune. Sediment at the locations of shore protection projects were comparatively finer and better sorted than the sediment immediately adjacent to the inlet. The placement of $\sim 2,300 \mathrm{~m}^{3}$ of upland mined sediment at R21 in 2016 likely influenced sorting at this location as well as the immediately adjacent downdrift beaches (CISNEROS et al. 2016). The similar carbonate content at the shore protection project locations and the non-nourished beach are attributed to the local contribution of weathered coquina and autochthonous biogenic materials. Difference in surface samples and samples taken at depth illustrate that surface samples may not be representative of the entire 3-dimensional sedimentology of a beach. Samples at the nonnourished beach were similar to the beaches nourished with offshore or upland mined sand, suggesting that borrow source material is similar to the native sediment. However, different patterns in sediment properties were measured at R34, where a nearby marine life facility uses a water intake pipe extending across the swash zone. Additional study is recommended to evaluate the local hydrodynamics to determine any influence on beach sediments.

Finer sediment at the MHW surface as compared to the mid-beach and dune likely due to a recent accretionary event or beach recovery within the dynamic swash zone. Initial sediment transport onshore has been documented to consist of a finer fraction of sediment as compared to more energetic periods resulting in coarser materials, such as seen at depth (ROBERTS et $a l ., 2013)$. The difference in surface sediments and those at depth illustrate the dynamic nature of beaches, with spatio-temporal variability and selective transport of sediments placed as nourishment.

The non-carbonate siliciclastic sediment texture and mineralogy were similar between locations with either well sorted or moderately well sorted sand, except at the more poorly sorted BUDM location. The similarity of the siliciclastic fraction is attributed to extensive reworking of shelf sediment and weathering during regional-scale longshore sediment transport. Clasts varied in color, including black, dark brown, purple, blue, and green, and were present in nearly all the samples in some quantity. The black and dark brown mineral grains were likely ilmenite and magnetite. Ilmenite is not magnetic, with generally subrounded clasts, and is one of few minerals that is rather resistant to weathering. Other black mineral grains in the sample were magnetic. These grains are few in quantity but appear in R21, R27, and R34 that have been nourished using upland sediment source. The upland sediment may not have experienced the same degree of weathering rates as in an aqueous environment. This might also explain the presence of magnetite, a mineral with moderate ability to resist weathering, in a location far from any obvious source. The other blue, pink, purple, or a reddish-brown grains were likely "beach glass", or heavily weathered broken glass (i.e., marine debris).

The beach slope prediction for protected beach exposure was closest to the measured slope at all locations. The combination of wave dissipation from the general bar and trough morphology and reduced fetch due to the large Bahamian archipelago contribute to the coasts' protected nature. Where measured beach slopes ranged between 1:7 to 1:14, the predicted beach slopes ranged from 1:7 to 1:15. The predicted slope was the same as the measured slope at 13A. This site had the largest median grain size, but it was sample immediately following the placement of BUDM and would have been actively undergoing post-nourishment profile equilibration and not likely accreting (WILLSON et al., 2019). The slope at the other locations were also very closely estimated by the protected beach exposure equation, except at R21. 
Although fine sediment is typically associated with more gentle slopes, it is likely that in this case the finer sediment at the MHW were from a period of onshore sediment transport resulting in a steeper foreshore. Therefore, caution is urged for predicting slopes using sediment collected during initial beach recovery (and perhaps immediately after major erosive events). Lastly, shallow or surficial outcropping bedrock at the shoreline and in the nearshore might have also influenced the foreshore slope in the area. Additional study is recommended to determine the role of antecedent geology, hydrodynamics, and timing of sampling events influence on local variability in sediment and beach slope.

\section{FINAL CONSIDERATIONS}

This study evaluated the sedimentology and morphology of nourished and non-nourished beaches in northern Palm Beach County, FL, USA. Surface sample textures varied alongshore and cross-shore, with the most poorly sorted and coarse sediment located at the inlet-adjacent site influenced by placement of BUDM. Sediment generally became progressively finer and better sorted downdrift at the surface and at depth. At depth, the cross-shore distribution of sediment followed the typical pattern of increased fining from the MHW to the mid-beach to the dune, whereas the MHW surface sample was finer than the landward locations. The nonnourished beach sediment was similar to the beaches with sediment placed from either offshore or upland mines. However, the difference in surface samples and samples taken at depth illustrate that surface samples may not be representative of the entire 3-dimensional sedimentology of a beach, which can have implications for drainage, sediment transport, and habitat.

Finer sediment at the MHW surface as compared to the mid-beach and dune were attributed to a recent accretionary or beach recovery event highlighting the dynamic nature of beaches and spatio-temporal variability and selective transport of sediments placed during nourishment. Carbonate content at the shore protection project locations and the non-nourished beach were likely dominated by the local contribution of weathered coquina and autochthonous biogenic materials. The non-carbonate siliciclastic sediment texture and mineralogy were similar between locations (again, except at the site of BUDM), consisting primarily of quartz clasts and few other minerals. The similarity of the siliciclastic fraction is attributed to extensive reworking of shelf sediment and weathering during regional-scale longshore sediment transport.

Measured foreshore slopes were best predicted using the protected beach equation for this study area. The predicted slope was the same as the measured slope at the BUDM site, which has a larger median grain size and in an unlikely scenario of accretion, as it was likely undergoing post-nourishment profile equilibration. In contrast, the other locations had comparatively finer sediment at the MHW which would have resulted in more gently sloping beaches. However, finer sediment at the MHW was attributed to a period of onshore sediment transport resulting in a steeper foreshore. Thus, the complicated spatio-temporal morphodynamics of beaches should be considered when using median grain size from only one sampling event.

In summary, results from this study illustrate the 3-dimensional spatial variability of the sedimentology and morphology of natural and managed beaches. Future studies are recommended to evaluate the influences time-series sampling, nearshore hydrodynamics, and antecedent geology on beach sediments and morphology. 


\section{ACKNOWLEDGEMENTS}

The authors would like to thank the Palm Beach County Department of Environmental Resources Management for partially funding the sediment analyses conducted in this study.

\section{REFERENCES}

ADRIAANSE, L. A.; COOSEN, J. Beach and dune nourishment and environmental aspects. Coastal Engineering, 16(1), 129-146, 1991.

ANDREW, D. Effects of Beach Nourishment on Sea Turtles: Review and Research Initiatives. Restoration Ecology, 95-104, 1995.

BASCOM, W. N. The relationship between sand size and beach-face slope. Eos, Transactions American Geophysical Union, 32(6), 866-874, 1951.

BENEDET, L.; FINKL, C. W.; KLEIN, A. H. F. Morphodynamic classification of beaches on the Atlantic coast of Florida: geographical variability of beach types, beach safety and coastal hazards. Journal of Coastal Research, 360-365, 2006.

BLACKLEY, M. W. L.; HEATHERSHAW, A. D. Wave and tidal-current sorting of sand on a wide surf-zone beach. Marine Geology, 49(3-4), 345-355, 1982.

BOGGS JR, S. Principles of sedimentology and stratigraphy. Pearson Education, 2014.

CISNEROS, J. A.; BRIGGS, T. R.; MARTIN, K. Placed sediment characteristics compared to sea turtle nesting and hatching patterns: a case study from Palm Beach County, FL. Shore \& Beach, 85(2), 35, 2017.

CHEN, C. L.; WANG, C. C.; CHENG, I. J. Effects of biotic and abiotic factors on the oxygen content of green sea turtle nests during embryogenesis. Journal of Comparative Physiology B, 180(7), 1045-1055, 2010.

DAVIS JR., R.A.; WANG, P.; SILVERMAN, B.R. Comparison of the performance of three adjacent and differently constructed beach nourishment projects on the Gulf Peninsula of Florida. Journal of Coastal Research 16 (2), 396-407, 2000.

DAVIS, R. A. Geology of the Florida coast. The Geology of Florida, 155-168, 1997.

DEAN, R. G. Beach nourishment: theory and practice (Vol. 18). World Scientific Publishing Company, 2003.

DE MEIJER, R. J.; BOSBOOM, J.; CLOIN, B.; KATOPODI, I.; KITOU, N.; KOOMANS, R. L.; MANSO, F. Gradation effects in sediment transport. Coastal Engineering, 47(2), 179$210,2002$.

DINGLER, J. R.; REISS, T. E. Changes to Monterey Bay beaches from the end of the 198283 El Niño through the 1997-98 El Niño. Marine Geology, 181(1-3), 249-263, 2002. 
FDEP. Critically Eroded Beaches In Florida, (August), 2016.

FDEP. Strategic Beach Management Plan: Southeast Atlantic Coast Region, (May), 2018.

FINKL, C. W.; BENEDET, L.; ANDREWS, J. L. Submarine geomorphology of the continental shelf off southeast Florida based on interpretation of airborne laser bathymetry. Journal of Coastal Research, 1178-1190, 2005.

FINKL, C. W.; KHALIL, S. M. Offshore exploration for sand sources: general guidelines and procedural strategies along deltaic coasts. Journal of Coastal Research, 203-233, 2005.

FUENTES, M. M. B.; LIMPUS, C. J.; HAMANN, M.; DAWSON, J. Potential impacts of projected sea-level rise on sea turtle rookeries. Aquatic conservation: marine and freshwater ecosystems, 20(2), 132-139, 2010.

GOLDICH, S. S. A study in rock-weathering. The Journal of Geology, 46(1), 17-58, 1938.

GRAIN, D. A.; BOLTEN, A. B.; BJORNDAL, K. A. Effects of beach nourishment on sea turtles: review and research initiatives. Restoration Ecology, 3(2), 95-104, 1995.

HORN, D. P.; WALTON, S. M. Spatial and temporal variations of sediment size on a mixed sand and gravel beach. Sedimentary Geology, 202(3), 509-528, 2007.

HOUSTON, J. R. Shoreline recession caused by inlets created or modified for navigation on the Florida southeast coast. Shore and Beach, 85(3), 47-56, 2017.

KARUNARATHNA, H.; HORRILLO-CARABALLO, J. M.; RANASINGHE, R.; SHORT, A. D.; REEVE, D. E. An analysis of the cross-shore beach morphodynamics of a sandy and a composite gravel beach. Marine Geology, 299, 33-42, 2012.

KRAUS, N. C.; GALGANO, F. A. Beach erosional hot spots: types, causes, and solutions (No. ERDC/CHL-CHETN-II-44). ENGINEER RESEARCH AND DEVELOPMENT CENTER VICKSBURG MS COASTAL AND HYDRAULICS LAB, 2001.

KOMAR, P. D.; WANG, C. Processes of selective grain transport and the formation of placers on beaches. The Journal of Geology, 92(6), 637-655, 1984.

KOMAR, P. D.; MCDOUGAL, W. G. The analysis of exponential beach profiles. Journal of Coastal Research, 59-69, 1994.

LACEBY, J. P.; EVRARD, O.; SMITH, H. G.; BLAKE, W. H.; OLLEY, J. M.; MINELLA, J. P.; OWENS, P. N. The challenges and opportunities of addressing particle size effects in sediment source fingerprinting: a review. Earth-Science Reviews, 169, 85-103, 2017.

LEADON, M. Beach slope and sediment-grain-size trends as a basis for input parameters for the SBEACH erosion model. Journal of Coastal Research, 31(6), 1375-1388, 2015.

LOONEY, P. B.; GIBSON, D. J. Vegetation monitoring of beach nourishment. In: Beach Nourishment Engineering and Management Considerations (p. 226-241). ASCE, 1993. 
MCFALL, B. C. The Relationship between Beach Grain Size and Intertidal Beach Face Slope. Journal of Coastal Research, 35(5), 1080-1086, 2019.

MCLEAN, R. F.; KIRK, R. M. Relationships between grain size, size-sorting, and foreshore slope on mixed sand-shingle beaches. New Zealand Journal of Geology and Geophysics, 12(1), 138-155, 1969.

MILTON, S. L.; SCHULMAN, A. A.; LUTZ, P. L. The effect of beach nourishment with aragonite versus silicate sand on beach temperature and loggerhead sea turtle nesting success. Journal of Coastal Research, 904-915, 1997.

MORTIMER, J. A. Reproductive Ecology of the Green Turtle, Chelonia mydas, at Ascension Island, 1982.

MORTIMER, J. A. The influence of beach sand characteristics on the nesting behavior and clutch survival of green turtles (Chelonia mydas). Copeia, 802-817, 1990.

MORTIMER, J. A. Factors influencing beach selection by nesting sea turtles, p. 45-51. Smithsonian Institution Press, Washington, DC, 1995.

NATIONAL BEACH NOURISHMENT DATABASE. 2020. Available from: https://gim2.aptim.com/ASBPANationwideRenourishment/.I

OLSEN ASSOCIATES INC.; COASTAL PLANNING AND ENGINEERING INC.

Feasibility Evaluation of Upland Truck Haul as a Beach Fill Construction Method in Broward County, FL - Segment II, 32204 (June 2012).

OUSLEY, J. D.; KROMHOUT, E.; SCHRADER, M. H.; LILLYCROP, L. Southeast Florida sediment assessment and needs determination (SAND) study. ENGINEER RESEARCH AND DEVELOPMENT CENTER VICKSBURG MS COASTAL AND HYDRAULICS LAB, 2014.

PETERSON, C. H.; BISHOP, M. J. Assessing the environmental impacts of beach nourishment. Bioscience, 55(10), 887-896, 2005.

PIKE, D. A.; ROZNIK, E. A.; BELL, I. Nest inundation from sea-level rise threatens sea turtle population viability. Royal Society Open Science, 2(7), 150127, 2015.

REIS, A. H.; GAMA, C. Sand size versus beachface slope - an explanation based on the constructal law. Geomorphology, 114(3), 276-283, 2010.

RIZKALLA, C. E.; SAVAGE, A. Impact of seawalls on loggerhead sea turtle (Caretta caretta) nesting and hatching success. Journal of Coastal Research, 27(1), 166-173, 2011.

ROBERTS, T. M.; WANG, P.; KRAUS, N. C. Limits of wave runup and corresponding beach-profile change from large-scale laboratory data. Journal of Coastal Research, 184$198,2010$. 
ROBERTS, T. M.; WANG, P.; PULEO, J. A. Storm-driven cyclic beach morphodynamics of a mixed sand and gravel beach along the Mid-Atlantic Coast, USA. Marine Geology, 346, 403-421, 2013.

RUMBOLD, D. G.; DAVIS, P. W.; PERRETTA, C. Estimating the effect of beach nourishment on Caretta caretta (loggerhead sea turtle) nesting. Restoration Ecology, 9(3), 304-310, 2001.

SALLENGER JR, A. H. Storm impact scale for barrier islands. Journal of Coastal Research, 890-895, 2000.

SCOTT, T. M. A geological overview of Florida, 1992.

SCOTT, T. M. Miocene to Holocene history of Florida. The geology of Florida, 57-68, 1997.

TURKOZAN, O.; YAMAMOTO, K.; YILMAZ, C. Nest site preference and hatching success of green (Chelonia mydas) and loggerhead (Caretta caretta) sea turtles at Akyatan Beach, Turkey. Chelonian Conservation and Biology, 10(2), 270-275, 2011.

\section{U.S. Army Corps of Engineers. Carolina Beach, NC Beach Renourishment Evaluation} Report. 2019a.

U.S. Army Corps of Engineers. Wrightsville Beach, NC Beach Renourishment Evaluation Report. WRIGHTSVILLE BEACH, NC BEACH RENOURISHMENT VALIDATION STUDY. 2019b.

WANG, P.; BECK, T. M. Morphodynamics of an anthropogenically altered dual-inlet system: John's Pass and Blind Pass, west-central Florida, USA. Marine Geology, 291, 162-175, 2012.

WARE, M.; LONG, J. W.; FUENTES, M. M. Using wave runup modeling to inform coastal species management: An example application for sea turtle nest relocation. Ocean \& coastal management, 173, 17-25, 2019.

WALKER, K. R.; SHANMUGAM, G.; RUPPEL, S. C. A model for carbonate to terrigenous clastic sequences. Geological Society of America Bulletin, 94(6), 700-712, 1983.

WIEGEL, R. L. Harbor Oscillations. Oceanographic Engineering, Prentice Hall, Englewood Cliffs, NJ, 115-125, 1964.

WILLSON, K.; THOMSON, G.; BRIGGS, T. R.; ELKO, N.; MILLER, J. Beach nourishment profile equilibration: What to expect after the sand is placed on a beach. Shore $\boldsymbol{\&}$ Beach, 85(2), p. 49-51, 2017.

WOOD, D. W.; BJORNDAL, K. A. Relation of temperature, moisture, salinity, and slope to nest site selection in loggerhead sea turtles. Copeia, 2000(1), 119-119. 